\title{
POTENSI DAN PERMUDAAN TEGAKAN ALAM EBONI (Diospyros celebica Bakh.) DI AREAL HPH PT. INHUTANI I MAMUJU
}

\author{
Potencies and Regeneration of Natural Stand of Eboni (Diospyros celebica Bakh.) in Consession Area \\ PT. Inhutani Mamuju
}

Muh. Restu

\begin{abstract}
The intensive use of Eboni has caused a decrease of its natural population which has also contributed to the future loss of genetic potencies. Preservation efforts could only be conducted if the actual potencies of the stand and its environmental conditions were recognized. A study on stand and regeneration potencies as well as its soil characteristics is needed as a basic in management aplication for the increase of genetic potencies. This study used a systematic sampling survey method and laboratory analysis. The study aims to identify tree potencies and regeneration of Eboni Makassar as well as its soil characteristics under the stand. The results are expected to provide a description on Eboni Makassar potencies and its management efforts. It was found from the study that the potency of Eboni was $5.013 \mathrm{~m}^{3} / \mathrm{ha}$ with minimum and maximum estimated volumes of $3.163 \mathrm{~m}^{3} / \mathrm{ha}$ and $6.863 \mathrm{~m}^{3} / \mathrm{ha}$, respectively. Eboni was naturally regenerated better in $>40 \%$ slope category.
\end{abstract}

Keywords: Eboni, Potencies and Regeneration, Various Slope

\section{PENDAHULUAN}

Pemanfaatan potensi hasil hutan kayu yang terdapat pada tegakan hutan, untuk berbagai keperluan, dilakukan terhadap jenis-jenis yang mempunyai nilai ekonomi yang tinggi. Kecenderungan pemanfaatannya ditekankan pada pemanenan hasil kayu, namun tidak diikuti dengan upaya peningkatan kualitas dan upaya permudaan, sehingga potensi yang ada semakin berkurang bahkan terdapat jenis tanaman hutan yang telah mengalami penurunan populasi yang sangat besar. $\mathrm{Hal}$ ini akan menyebabkan hilangnya potensi sumberdaya genetik. Jenis vegetasi hutan yang terdapat di wilayah Sulawesi, yang di indikasikan telah mengalami penurunan potensi adalah Eboni (Diospyros celebica Bakh.).

Eboni adalah termasuk famili Ebenaceae, merupakan tumbuhan endemik pada hutan alam di Pulau Sulawesi. Jenis ini sering disebut dengan kayu hitam, karena kayunya yang berwarna hitam. Potensi Eboni di Sulawesi Selatan yang cukup besar terdapat di Wilayah Malili dan Mamuju. Akibat pengambilan dan eksploitasi yang berlebihan, maka populasinya mulai berkurang dan jenis ini sudah termasuk dalam kategori rawan (vernerable). Lokasi sebaran tumbuh Eboni Makassar, juga ditemukan pada kawasan hutan di kabupaten Maros, Bone, Barru dan Sidrap.
Terjadinya penurunan potensi Eboni, sehingga dilakukan penelitian mengenai potensi tegakan dan sifat tanah dibawah tegakan. Penelitian ini bertujuan untuk mengetahui potensi pohon dan regenerasi jenis Eboni serta beberapa sifat fisik dan kimia tanah di bawah tegakan di areal HPH PT. Inhutani I Satuan Wilayah Mamuju. Penelitian ini diharapkan sebagai bahan untuk melakukan upaya pengelolaan yang lestari khususnya jenis Eboni.

\section{BAHAN DAN METODE}

Penelitian ini dilaksanakan dengan tahapan kegiatan berupa pengambilan data di lapangan dan analisis di laboratorium. Penelitian dilakukan pada tegakan eboni di areal HPH PT. Inhutani I Satwil Mamuju, Kecamatan Kalukku, Kabupaten Mamuju Data yang dikumpulkan dengan metode survay secara sistematik sampling dengan plot sampel sebanyak 40 plot, untuk mendapatkan potensi pohon dan potensi regenerasi berdasarkan perbedaan kelerengan lokasi. Variabel yang diamati yaitu pengukuran diameter pohon (d), tinggi bebas cabang pohon (tbc) dan volume pohon (v). 


\section{Potensi Pohon}

Analisis data untuk perhitungan volume tegakan menggunakan rumus sebagai berikut :

$\mathrm{V}$ total $=\mathrm{lbds} \times \mathrm{tbc} \times \mathrm{f}$

Perhitungan volume rata-rata per luasan digunakan langkah-langkah sebagai berikut :

$$
\begin{aligned}
& \mathrm{V}=\frac{\sum v i}{n} \\
& \mathrm{~S}_{\mathrm{v}}^{2}=\frac{\sum\left(\mathrm{vi}^{2}\right)-\left(\sum \mathrm{vi}\right)^{2} / \mathrm{n}}{n-1} \\
& \mathrm{~S}_{\mathrm{v}}=\sqrt{\mathrm{S}_{\mathrm{v}}^{2}} \\
& \mathrm{~S}_{\mathrm{v}}=\frac{\mathrm{S}_{\mathrm{v}}}{\sqrt{\mathrm{n}}} \sqrt{\left[1-\frac{\mathrm{n}}{\mathrm{N}}\right]} \\
& \mathrm{SE}=\mathrm{t}_{(1-1 / 2 \gamma)} \mathrm{S}_{\mathrm{v}}
\end{aligned}
$$

\section{Potensi Regenerasi}

Potensi regenerasi di hitung dengan mengetahui jumlah individu yang menggambarkan kerapatan per hektar. Kerapatan individu dihitung untuk tingkat pertumbuhan semai, pancang, tiang dan pohon.

\section{HASIL DAN PEMBAHASAN}

\section{Luas Bidang Dasar dan Volume Pohon}

Luas bidang dasar (LBDS) berdasarkan perbedaan kelerengan bervariasi berdasarkan strata tegakan. Kelas lereng $\mathrm{V}$ (lebih besar $40 \%$ ) mempunyai LBDS lebih besar dibanding kelas lainnya. Perbedaan ini disebabkan sebaran Eboni yang berbeda pada berbagai kelas lereng. Pada kelas lereng $\mathrm{V}$ terdiri atas strata yang lengkap, termasuk tingkat pohon. Berdasarkan sifat silvik Eboni, yang semi toleran, yang membutuhkan naungan pada fase semai, maka kelas lereng $\mathrm{V}$, sangat mendukung proses regenerasi alami. Hasil perhitungan LBDS, disajikan pada Tabel 1.

Table 1. Diameter width of Eboni Makassar for each slope category

\begin{tabular}{lrrrr}
\hline \multirow{2}{*}{$\begin{array}{c}\text { Slope } \\
\text { Category } \\
(\%)\end{array}$} & Tree & Pole & Sapling & Total \\
\cline { 2 - 5 } I $(0-8 \%)$ & - & - & - & - \\
II (8-15\%) & - & - & - & - \\
III (15-25\%) & - & 0,04 & 0,012 & 0,052 \\
IV $(25-40 \%)$ & - & 0,08 & 0,017 & 0,097 \\
V (> 40\%) & 0,81 & 0,34 & 0,02 & 1,17 \\
\hline Jumlah & 0,81 & 0,46 & 0,049 \\
\hline
\end{tabular}

Berdasarkan hasil perhitungan potensi volume eboni, menunjukkan bahwa rata-rata potensi per hektar adalah $5,013 \mathrm{~m}^{3}$, dengan taksiran volume minimum rata-rata adalah $3,163 \mathrm{~m}^{3}$ dan maksimum adalah $6,863 \mathrm{~m}^{3}$. Potensi tersebut tergolong rendah jika dibandingkan dengan potensi kayu EboniMakassar yang ada di areal Sulawesi Tengah yang dapat mencapai $60 \mathrm{~m}^{3} / \mathrm{Ha}$. Rendahnya potensi eboni ini karena kegiatan penebangan yang intensif serta gangguang terhadap habitat sehingga regenerasi tidak berlangsung dengan baik (Riswan, 2002).

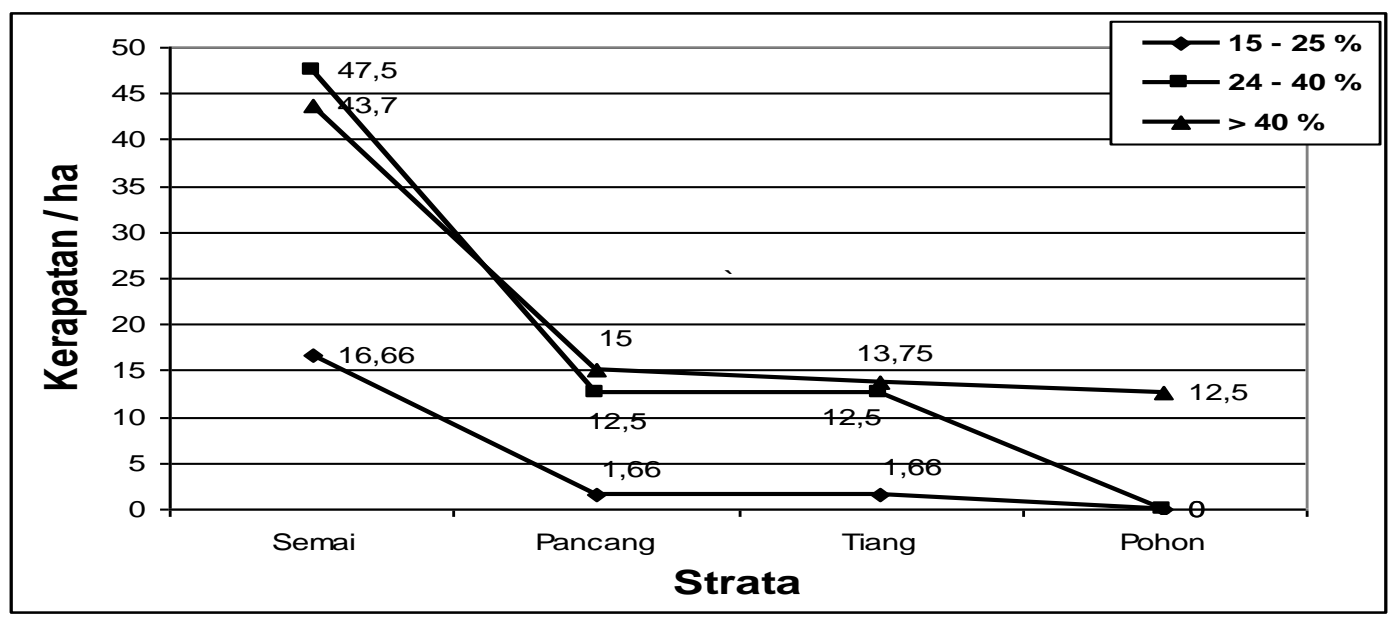

Figure 1. Density Distribution Graph in each Slope Category 


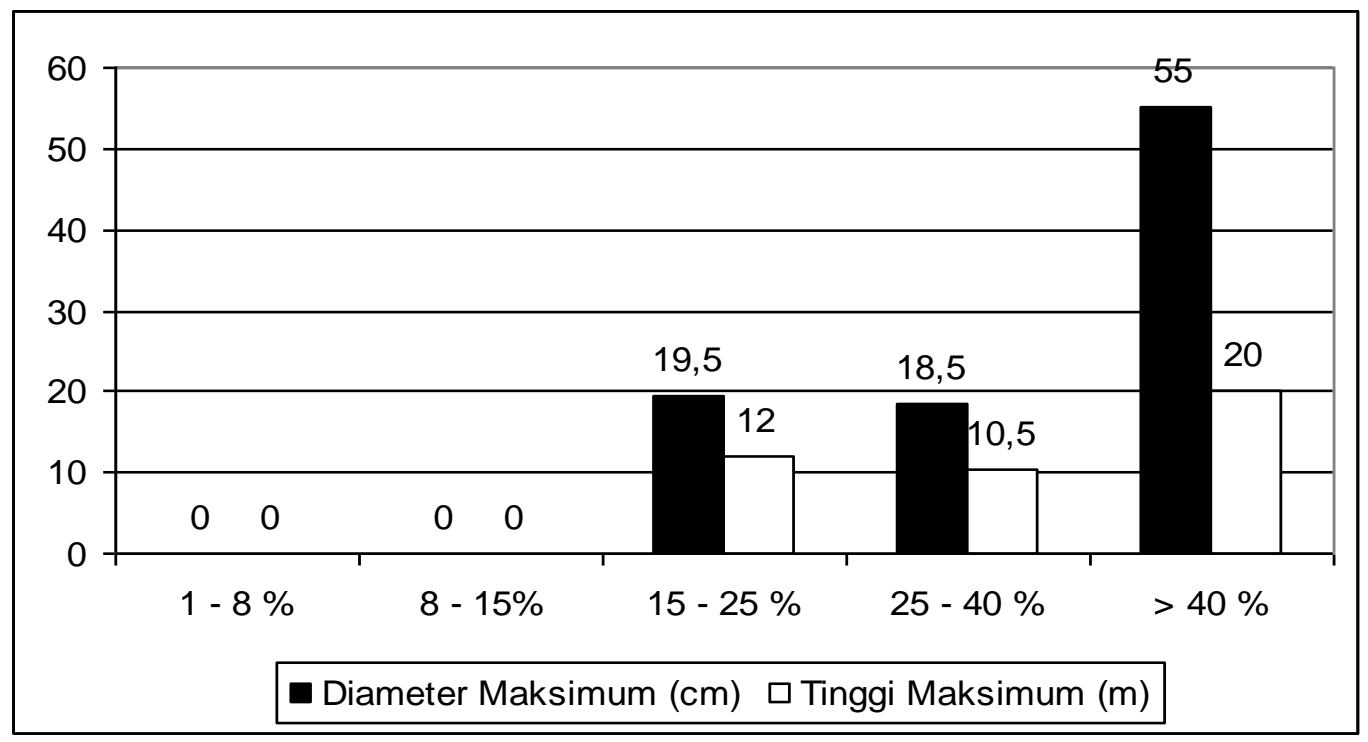

Figure 2. Histogram of Maximum Diameter and Height in each slope category

\section{Diameter dan Tinggi}

Pertumbuhan diameter dan tinggi yang maksimum, terdapat pada kelas lereng $40 \%$. Adanya perbedaan ini sebagai pengaruh kondisi kelerengan dengan keadaan tanah. Riswan (2002) mengemukan bahwa pada kelerengan yang lebih besar dan kondisi tanah yang permeabel, sangat mendukung pertumbuhan Eboni. Pohon dengan diamater yang besar diatas $20 \mathrm{~cm}$ atau termasuk tingkat pohon hanya ditemukan pada kelas lereng lebih besar $40 \%$. Sedangkan tinggi maksimum mecapai 20 meter. Adapun distribusi diamater dan tinggi berdasarkan kelas lereng terdapat pada Gambar 2.

\section{KESIMPULAN}

1. Potensi volume pohon eboni tergolong rendah

2. Proses permudaan alam Eboni pada kelas kelerengan $>40 \%$, berlangsung dengan baik.

\section{DAFTAR PUSTAKA}

Allo M.K, 2002. Eboni dan Habitatnya. Berita Biologi Manajemen Eboni (Diospyros celebica Bakh.) Dalam mendukung Keunggulan Industri Menuju otonomisasi dan Era Pasar Bebas, Volume 6, Makassar.

Riswan, S. 2002. Kajian Biologi Eboni (Diospyros celebica Bakh.). Berita Biologi Manajemen Eboni (Diospyros celebica Bakh.) Dalam mendukung Keunggulan Industri Menuju otonomisasi dan Era Pasar Bebas, Volume 6, Makassar.

Santoso, B., C. Anwar dan S. Nompo, 2002. Pembudidayaan Pohon Eboni (Diospyros celebica Bakh.). Berita Biologi Manajemen Eboni (Diospyros celebica Bakh.) Dalam mendukung Keunggulan Industri Menuju otonomisasi dan Era Pasar Bebas, Volume 6, Makassar.

Diterima : 15 Mei 2006

Muh. Restu

Lab. Silvikultur, Jurusan Kehutanan, Universitas Hasanuddin Kampus Tamalanrea, Jl. Perintis Kemerdekaan Km. 10, Makassar 90245

Telp./Fax. 0411-585917. Indonesia 